\title{
B5, a thioredoxin reductase inhibitor, induces apoptosis in human cervical cancer cells by suppressing the thioredoxin system, disrupting mitochondrion-dependent pathways and triggering autophagy
}

\author{
Fang-Yuan Shao ${ }^{1, *}$, Zhi-Yun Du${ }^{3, *}$, Dong-Lei Ma², Wen-Bo Chen ${ }^{2}$, Wu-Yu Fu' \\ Bi-Bo Ruan', Wen Rui ${ }^{1}$, Jia-Xuan Zhang ${ }^{2}$, Sheng Wang ${ }^{2}$, Nai Sum Wong ${ }^{4}$, \\ Hao Xiao ${ }^{5}$, Man-Mei Li ${ }^{2}$, Xiao Liu ${ }^{1}$, Qiu-Ying Liư ${ }^{2}$, Xiao-dong Zhou ${ }^{6}$, Hai-Zhao Yan ${ }^{2}$, \\ Yi-Fei Wang ${ }^{2}$, Chang-Yan Chen', Zhong Liư ${ }^{2}$, Hong-Yuan Chen ${ }^{1}$ \\ ${ }^{1}$ Department of Pathogen Biology and Immunology, School of Basic Course, Guangdong Pharmaceutical University, \\ Guangzhou, P.R. China \\ ${ }^{2}$ Guangzhou Jinan Biomedicine Research and Development Center, Guangdong Provincial Key Laboratory of Bioengineering \\ Medicine, National Engineering Research Center of Genetic Medicine, Jinan University, Guangzhou, China \\ ${ }^{3}$ Institute of Natural Medicine \& Green Chemistry, School of Chemical Engineering and Light Industry, Guangdong University \\ of Technology, Guangzhou, China \\ ${ }^{4}$ Department of Biochemistry, Li Ka Shing Faculty of Medicine, The University of Hong Kong, Hong Kong, China \\ ${ }^{5}$ University of the Chinese Academy of Sciences, Beijing, China \\ ${ }^{6}$ Department of Gastroenterology, The First Affiliated Hospital of Nanchang University, Nanchang, China \\ ${ }^{7}$ Center for Drug Discovery, Northeastern University , Boston, MA, USA \\ *These authors have contributed equally to this work
}

Correspondence to:

Zhong Liu, e-mail: tliuzh@jnu.edu.cn

Hong-Yuan Chen, e-mail: hychen1208@126.com

Keywords: curcumin analog, thioredoxin reductase, cervical cancer, apoptosis

Received: March 26, 2015

Accepted: August 24, 2015

Published: September 04, 2015

\section{ABSTRACT}

The synthetic curcumin analog B5 is a potent inhibitor of thioredoxin reductase (TrxR) that has potential anticancer effects. The molecular mechanism underlying B5 as an anticancer agent is not yet fully understood. In this study, we report that B5 induces apoptosis in two human cervical cancer cell lines, CaSki and SiHa, as evidenced by the downregulation of XIAP, activation of caspases and cleavage of PARP. The involvement of the mitochondrial pathway in B5-induced apoptosis was suggested by the dissipation of mitochondrial membrane potential and increased expression of pro-apoptotic Bcl-2 family proteins. In B5-treated cells, TrxR activity was markedly inhibited with concomitant accumulation of oxidized thioredoxin, increased formation of reactive oxygen species (ROS), and activation of ASK1 and its downstream regulatory target $\mathrm{p} 38 / \mathrm{JNK}$. B5-induced apoptosis was significantly inhibited in the presence of $\mathrm{N}$-acetyl-I-cysteine. Microscopic examination of B5-treated cells revealed increased presence of cytoplasmic vacuoles. The ability of B5 to activate autophagy in cells was subsequently confirmed by cell staining with acridine orange, accumulation of LC3-II, and measurement of autophagic flux. Unlike B5-induced apoptosis, autophagy induced by B5 is not ROS-mediated but a role for the AKT and AMPK signaling pathways is implied. In SiHa cells but not CaSki cells, B5-induced apoptosis was promoted by autophagy. These data suggest that the anticarcinogenic effects of B5 is mediated by complex interplay between cellular mechanisms governing redox homeostasis, apoptosis and autophagy. 


\section{INTRODUCTION}

The thioredoxin (Trx) system, composed of thioredoxin reductase (TrxR), Trx, and NADPH, is a major cellular redox control mechanism that is often deregulated in malignancy [1]. The Trx system has special significance in tumor biology as tumor cells are often subject to oxidative stress arising from the tumor environment [2] and increased consumption of reducing equivalents to support DNA synthesis [3, 4]. The Trx system may be involved in carcinogenesis in several ways. Firstly, it can promote cancer cell proliferation through its modulatory effect on redox-regulated transcription factors and/or protein kinase signaling cascades [5]. Secondly, the Trx system is needed for the activity of peroxiredoxins [6], which are ubiquitously expressed antioxidant enzymes that scavenge reactive oxygen species (ROS) $[7,8]$ and the direct inhibition of apoptosis signal-regulating kinase 1 (ASK1) [9], a mitogenactivated protein kinase (MAPK) kinase kinase (MAPKKK) that activates the p38 and JNK MAPK pathways. As a result, tumor cells usually have higher resistance against oxidative stress-induced apoptosis [10]. Thirdly, the Trx system has also been implicated in tumor angiogenesis [11] through the induction of hypoxia-inducible factor 1 (HIF-1) and vascular endothelial growth factor (VEGF) [12], and the Trx-dependentheme oxygenase-1 (HO-1) pathway [13]. Fourthly, high levels of Trx expression are associated with tumor invasion and metastasis. Thus, Trx promotes matrix metalloproteinase activity and stimulates cancer cell invasion [14]. Trx over expression is linked to tumor metastasis [15] and is implicated in malignant potential of tumor cells [1]. Indeed, Trx levels are upregulated in the plasma of cancerpatients [16] and a high Trx level is often correlated with cancer resistance to chemotherapeutic agents [17-20]. Thus, the Trx system may represent an important therapeutic target in cancer treatment.

TrxR is a ubiquitously expressed selenocysteine (Sec)-containing oxidoreductase that catalyzes the NADPH-dependent reduction of Trx [21]. In our previous study, B5 as one of the synthetic curcumin analogs with structure shown in Figure 1A was found to potently inhibit TrxR by covalent modification of Cys497 and Sec 498 [22]. However, the potential anticancer effects of B5 have not been examined. The aim of the present study was to investigate the mechanisms of action of this TrxR inhibitor in two human cervical cancer cell lines CaSki and SiHa.

\section{RESULTS}

\section{Effects of B5 on the growth of CaSki and SiHa cells}

The effect of B5 and on cellular viability in comparison to curcumin was examined in the Caski and $\mathrm{SiHa}$ human cervical cancer cells. In MTT assay, the $\mathrm{IC}_{50}$ values of $\mathrm{B} 5$ and curcumin were respectively 6.1 and
$28.3 \mu \mathrm{M}$ in CaSki cells. In SiHa cells, the $\mathrm{IC}_{50}$ values were 5.3 and $18.5 \mu \mathrm{M}$, respectively (Fig. 1B). These results show that B5 is relatively more cytotoxic towards cancer cells than natural curcumin.

\section{B5 induces cell cycle arrest and apoptosis in CaSki and SiHa cells}

To study the mechanism underlying the inhibitory effects of B5 on cancer cell growth, cell-cycle analysis was performed for B5-treated CaSki and SiHa cells by flow cytometry. The treatment of cells with B5 $(16 \mu \mathrm{M})$ resulted in an increase in the percentage of cells in the $\mathrm{G} 2 / \mathrm{M}$ phases by $18 \%$ and $10 \%$ respectively in the CaSki and $\mathrm{SiHa}$ cells when compared to the controls. A similar increase in the percentage of $\mathrm{G} 2 / \mathrm{M}$ cells was again observed after treating the cells with B5 at $32 \mu \mathrm{M}$ (Fig. 2A).

Whether the treatment of cells with B5 would also result in apoptosis was next examined. Cells were stained with a mixture of Annexin-V-FITC/PI followed by flow cytometry analysis. B5 at 16 and $32 \mu \mathrm{M}$ caused readily detectable cell death to occur in both cell lines as evident by the presence of cells stained positively with Annexin V-FITC only (early apoptotic) or Annexin-V-FITC/PI (late apopotic). In the CaSki cells, B5 at 16 and $32 \mu \mathrm{M}$ caused a small but distinct increase in the percentage of early apoptotic cells. By contrast, a rather large increase in the percentage of late apoptotic cells amounting to $58.7 \%$ and $60.5 \%$ respectively at 16 and $32 \mu \mathrm{M}$ of B5 was observed. Similarly, more late than early apoptotic cells were formed in B5-treated SiHa cells. At B5 concentrations of 16 and $32 \mu \mathrm{M}$, the percentage late apoptotic cells was approximately double that of the untreated control.

We next analyzed the effect of B5 on the activation of caspases and expression of XIAP. Western blotting analysis showed that B5 induced the activation of caspase 3, caspase 8, and caspase 9. Consistent with the activation of caspases, the caspase 3 substrate PARP was found to undergo specific proteolytic cleavage as suggested by the presence of the $116 \mathrm{kDa}$ to $89 \mathrm{kDa}$ fragment in cells treated with B5 at 4,16 and $32 \mu \mathrm{M}$ in CaSki cells. In the case for $\mathrm{SiHa}$ cells, an increase in the abundance of the $89 \mathrm{kDa}$ PARP fragment could readily be seen in cells treated with B5 at $32 \mu \mathrm{M}$ (Fig. 2C). In addition, B5 treatment downregulated the expression of XIAP (Fig. 2C), which is considered the most potent human IAP protein currently identified because it inhibits the activity of both caspase 3 and caspase $9[23,24]$. These results suggest that caspases activation may underlie the apoptotic activity of B5 in cervical cancer cells.

\section{B5 induces mitochondrial dysfunction and regulates the expression of $\mathrm{Bcl}-2$ family proteins}

A distinctive feature of the early phase apoptosis is a change in mitochondrial membrane potential $\left(\Delta \psi_{\mathrm{m}}\right)[25]$ 
A<smiles>COc1cc(/C=C2\CC/C(=C\c3cc(OC)c(O)c(OC)c3)C2=O)cc(OC)c1O</smiles>

\section{B}
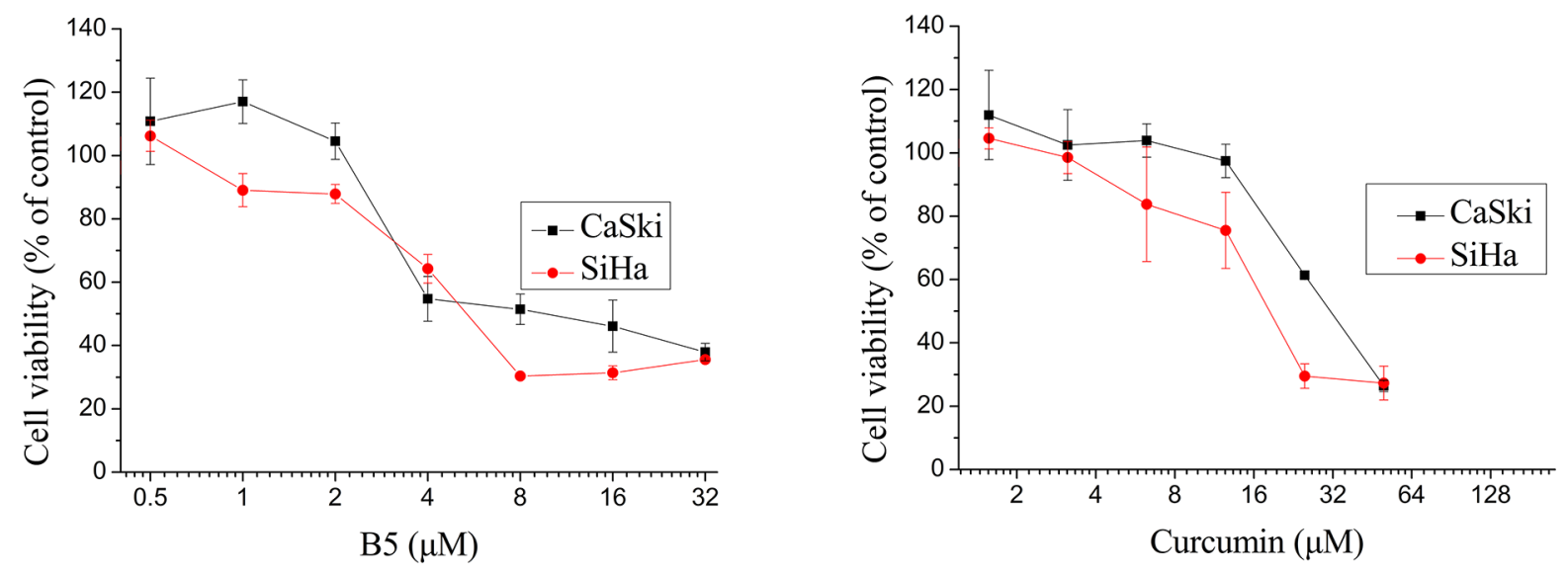

Figure 1: Effects of B5 and curcumin on cell growth. A. Chemical structure of B5. B. Effects of B5 and curcumin on cell growth. CaSki and SiHa cells were treated with the indicated concentrations of B5 or curcumin for $48 \mathrm{~h}$; cell viability was quantified by the MTT assay. Data are the mean \pm SD of at least three independent experiments.

that is an important parameter of mitochondrial function. The $\Delta \psi_{\mathrm{m}}$ is an early event preceding caspase activation, and is regarded as a hallmark of apoptosis [26]. Therefore, we measured $\Delta \psi_{\mathrm{m}}$ in B5-treated CaSki and $\mathrm{SiHa}$ cells using the membrane-permeable JC-1 dye. In apoptotic or unhealthy cells with low $\Delta \psi_{\mathrm{m}}$, JC-1 remains in the monomeric form, which has green fluorescence [27]. As shown in Fig. 3B, a marked increase in JC-1related green fluorescence can be seen in both the CaSki and $\mathrm{SiHa}$ cells treated with 16 or $32 \mu \mathrm{M}$ of B5. These results demonstrate that $\mathrm{B} 5$ induced MMP disruption in both cell lines.

Mitochondrion-mediated intrinsic apoptotic pathway occurs in response to various stimuli, including oxidative stress, and is regulated by the proteins of the Bcl-2 family [28, 29]. In this study, we found that B5 induced downregulation of antiapoptotic Bcl-xL, upregulation of proapoptotic Bid/Bok, and activation of Bim cleavage in CaSki cells (Fig. 3A). However, the expression of Bax and Bcl-2 was not affected by B5 (data not shown). These results indicate that B5 induces apoptosis of cancer cells through induction of mitochondrial dysfunction caused by deregulation of Bcl-2 family proteins.

\section{Effect of B5 on ROS generation}

ROS have important roles in intracellular signal transduction and redox homeostasis [30]. However, excessive ROS accumulation can exert toxic effects and cause oxidative stress, damaging main cellular components such as DNA, lipids, and proteins [31] and causing apoptosis [32]. To investigate whether B5-induced apoptosis was related to the changes in intracellular redox environment, we examined intracellular ROS production in B5-treated cervical cancer cells using DCFH-DA. As shown in Fig. 4A, B5 caused ROS accumulation in CaSki and SiHa cells, especially after the treatment for 3 and $2 \mathrm{~h}$, respectively. The pre-treatment of NAC, a ROS scavenger, reduced B5-induced apoptosis by $10.5 \%$ and $13.4 \%$, respectively (Fig. 4B). Together, these results suggest that ROS accumulation plays an important role in B5-induced cell apoptosis. 
A
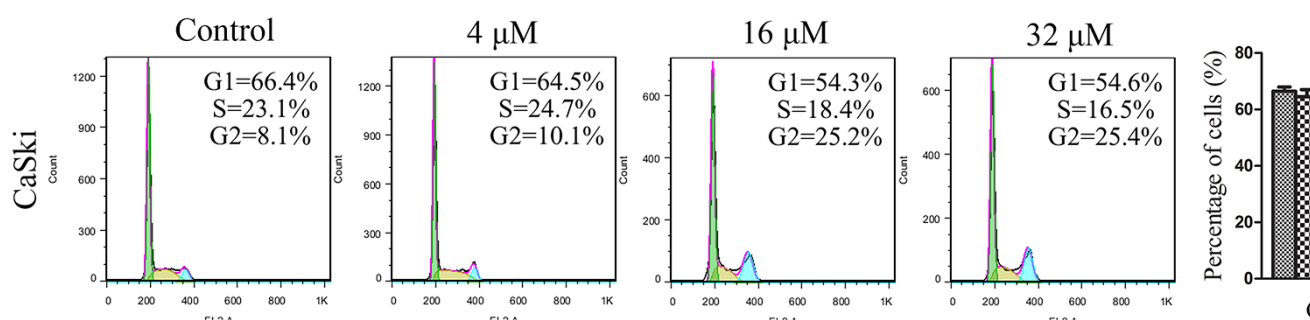

control

图 $4 \mu \mathrm{M}$

20
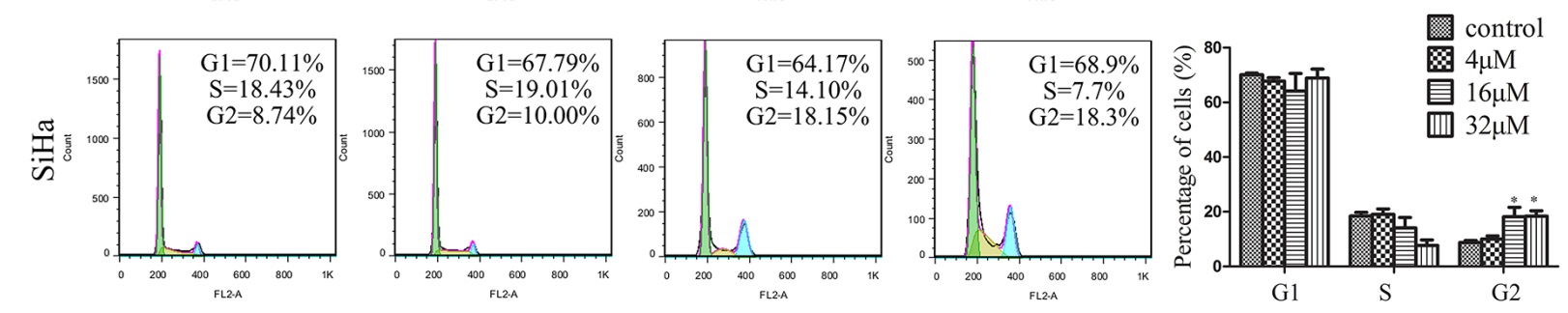

B


$\mathrm{C}$

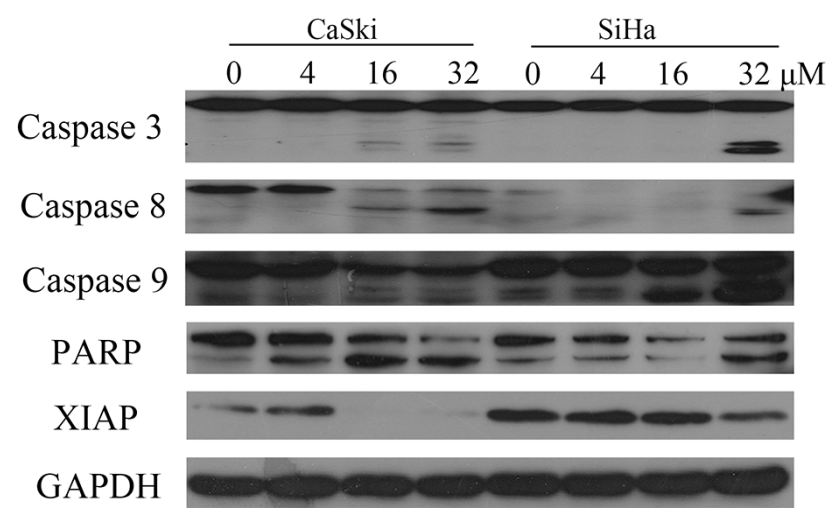

Figure 2: B5 induced apoptosis and cell cycle arrest in CaSki and SiHa cells. A. Effects of B5 on cell cycle distribution. Cells were treated with $0,4,16$, and $32 \mu \mathrm{M}$ B5 for $48 \mathrm{~h}$, fixed in 70\% ethanol, stained with PI, and cell cycle distribution was assessed by flow cytometry. The percentage of cells in each cell cycle phase is indicated as the mean \pm SD of three independent experiments. B. Induction of apoptosis by B5 in CaSki and SiHa cells. Cells were treated as above and analyzed by flow cytometry after Annexin-V-FITC/PI staining; data are presented as the mean $\pm \mathrm{SD}$ of three independent experiments. ${ }^{*} P<0.5$ and $* * P<0.01$. C. Western blotting analysis of the expression of the following: pro- and cleaved-caspases 3, 8, and 9; PARP (86kDa); and XIAP. Data are representatives of three independent experiments. 


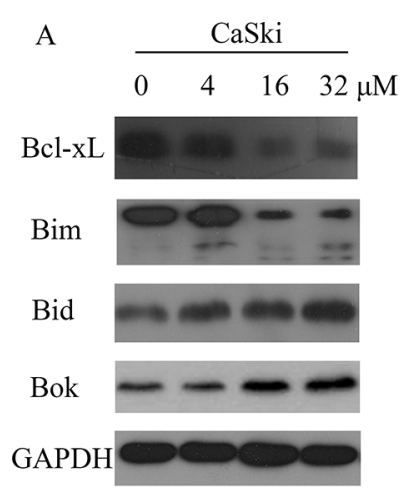

B

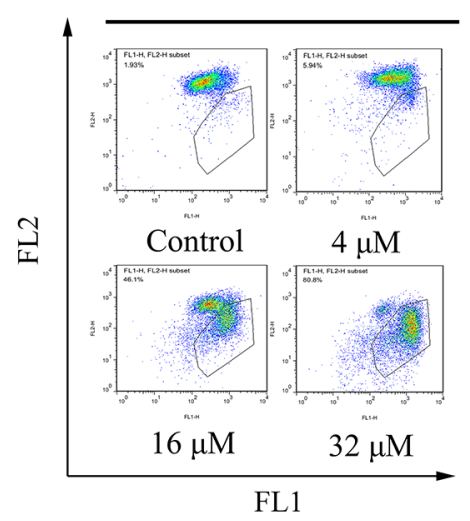

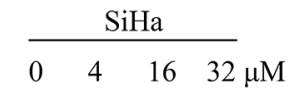
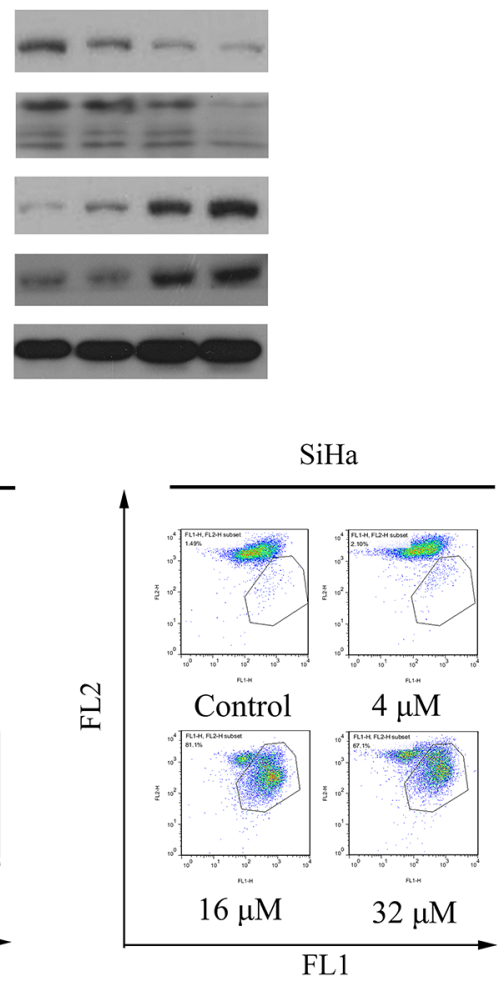

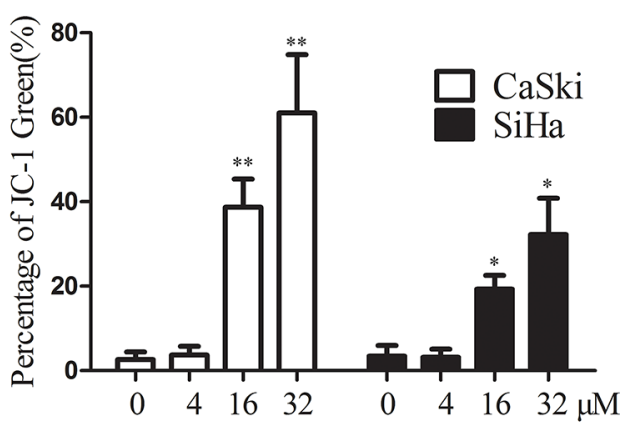

Concentration of B5

Figure 3: Effects of $\mathrm{B5}$ on the Bcl-2 family proteins and mitochondrial membrane potential (MMP). A. Expression of the Bcl-2 proteins was analyzed by western blotting, with GAPDH used as the internal control. B. Flow cytometry analysis of MMP by JC-1 staining. Cells were treated with $0,4,16$, and $32 \mu \mathrm{M}$ B5 for $48 \mathrm{~h}$ and stained with JC-1 for $20 \mathrm{~min}$. Cells with MMP loss were gated. Data are presented as the mean $\pm \mathrm{SD}$ of three independent experiments. $* P<0.5$ and $* * P<0.01$.

\section{Effect of B5 on the Trx system}

We next examined B5 effects on the Trx system. SC-TrxR assay showed that B5 inhibited TrxR activity dose-dependently in both cell lines (Fig. 5A). Interestingly, the expression level of Trx was increased in both cell lines, whereas that of TrxR was increased in $\mathrm{SiHa}$ cells but decreased in CaSki cells (Fig. 5B). This result was further verified by the RT-PCR assay: B5 upregulated Trx mRNA in both cell lines, while TrxR mRNA was upregulated only in SiHa cells (Fig. 5C). Nevertheless, the oxidized Trx form was increased while the reduced form was decreased dose-dependently in both cell lines after the treatment with B5 (Fig. 5D). Together, these results indicate that B5 deregulates the Trx system in cancer cells.

\section{Effect of B5 treatment on the MAPK signaling in cervical cancer cells}

The inhibition of TrxR activity should result in the shift of Trx redox state to the oxidized form (Fig. 5C) and dissociation of ASK1 from the complex with Trx [10]. In our study, co-immunoprecipitation assay showed that B5 induced the release of ASK1 from the complex with Trx (Fig. 6A). The increased presence of free ASK1 was also indicated by the activation of downstream MAPK signaling pathways mediated by ASK1: the phosphorylation level of p38 and JNK MAPKs notably increased in a time-dependent manner (Fig. 6B), suggesting activation of these kinases in CaSki and $\mathrm{SiHa}$ cells after B5 treatment.

\section{B5 induces autophagy in cervical cancer cells}

It is unclear whether autophagy in dying cells is the cause of cell death or is actually an attempt to prevent it. Autophagy-related cell death has been defined as a form of programmed cell death [33]. The treatment with $16 \mu \mathrm{M}$ B5 for $48 \mathrm{~h}$ induced autophagy in CaSki and SiHa cells, as demonstrated by the presence of autophagic vacuoles by electron microscopy (Fig. 7A). To confirm B5-induced autophagy, acridine orange, a lysosome marker dye, was used to stain CaSki and SiHa cells [34]. As shown in Fig. 7B, B5 induced the accumulation of acridine orange in cytoplasm of CaSki and SiHa cells, while less accumulation of acridine orange was observed in control 
A
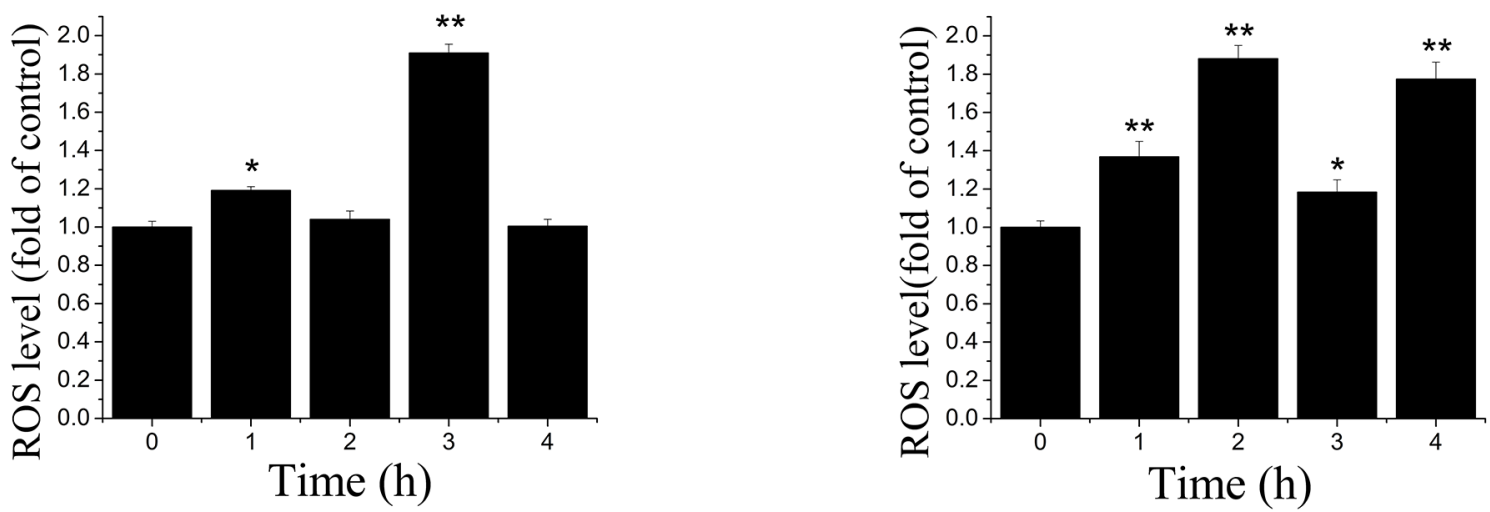

B


Late apoptosis Early apoptosis Total apoptosis ratio ratio ratio

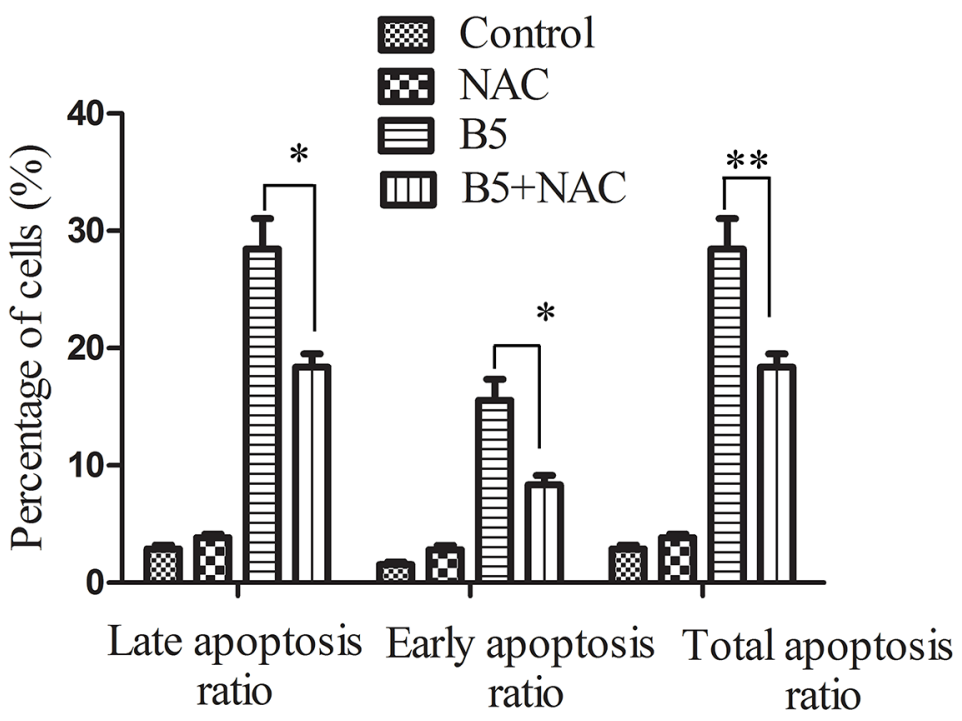

Figure 4: The role of ROS production in B5-induced cell apoptosis. A. B5-induced ROS production in CaSki (left) and SiHa (right) cells. Cells were treated with $16 \mu \mathrm{M}$ B5 for 1-4 h, stained with DCFH-DA for $20 \mathrm{~min}$, and analyzed for fluorescence at $525 \mathrm{~nm}$. B. B5-induced CaSki and SiHa cell apoptosis was inhibited by NAC pre-treatment. Cells were pre-treated with $10 \mathrm{mM} \mathrm{NAC} \mathrm{for} 30$ min and treated with $16 \mu \mathrm{M}$ B5 for $48 \mathrm{~h}$; then, they were stained with Annexin-V-FITC/PI and analyzed by flow cytometry. All values are presented as the mean $\pm \mathrm{SD}$ of three independent experiments. $* P<0.5$ and $* * P<0.01$. 
A

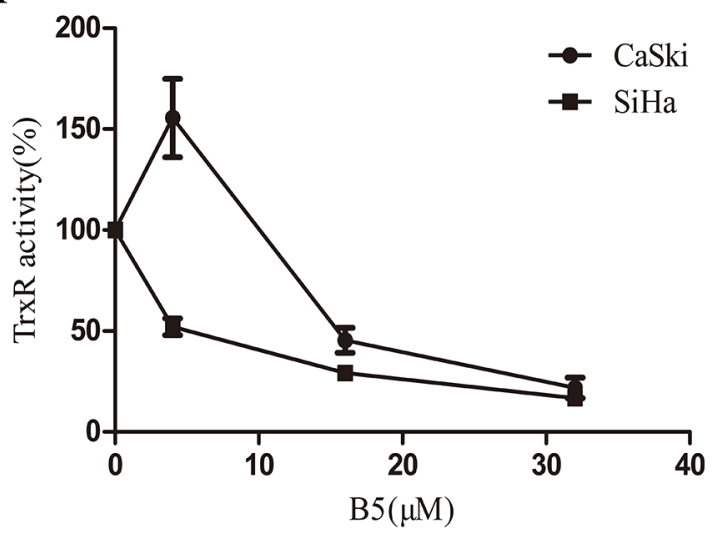

$\mathrm{C}$

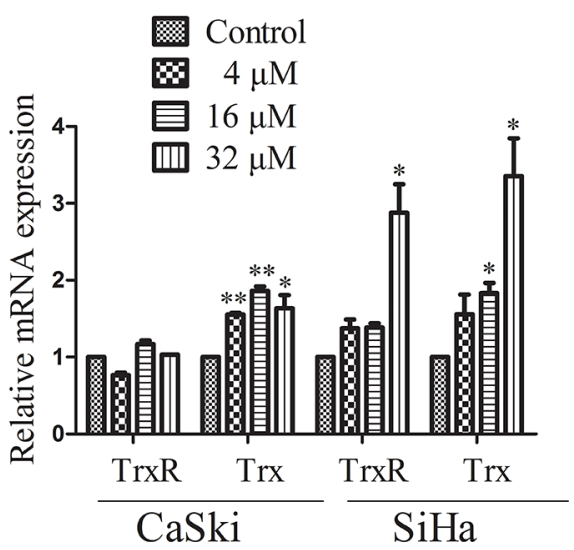

B

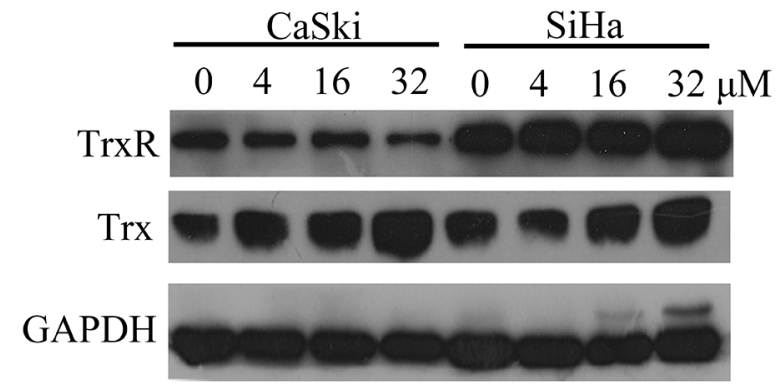

$\mathrm{D}$

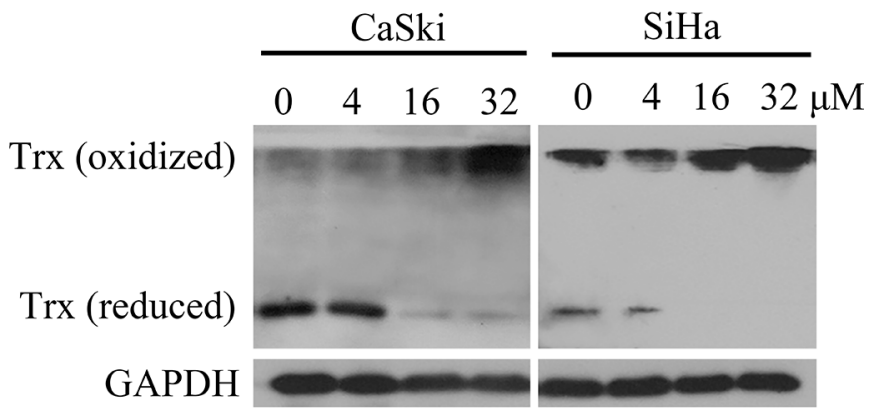

Figure 5: Effects of B5 on the Trx system. Cells were treated with 0, 4, 16 and $32 \mu \mathrm{M}$ B5 for 48 h. A. TrxR activity in cell lysates was determined by SC-TrxR assay. Data were presented as the percentage of control. B. Trx and TrxR protein levels were analyzed by SDSPAGE and western blotting. C. The mRNA levels of Trx and TrxR were measured by RT-PCR; GAPDH was used as an internal control. D. Trx redox status was determined by non-reduced SDS-PAGE and western blotting analysis; GAPDH was used as the internal control. All data are representatives of three independent experiments.

cells. Furthermore, B5 also induced accumulation of LC3-II (Fig. 7D), a lipidated form of LC3 that is regarded as an autophagosomal marker in mammals. To obtain further confirmation of autophagy, autophagic flux was measured in terms of alteration of LC3-II and SQSTM1/ p62 levels in the presence and absence of specific lysosomal inhibitors BAF and CQ that act to prevent autophagosomal lysosome degradation [35]. As shown in Fig. 7D, BAF or CQ treatment resulted in accumulation of LC3-II and SQSTM1/p62 both in CaSki and SiHa cells. The accumulation of LC3-II was increased and that of SQSTM1/p62 was decreased with the combination of inhibitors with B5. These results suggest that B5 induces autophagy in cervical cancer cells.

The AKT-mediated signaling cascade is one of the main signaling pathways regulating autophagy [36]. Figure 8A showed that the phosphorylation level of AKT was declined after B5 treatment, suggesting the involvement of the AKT signaling in B5-induced autophagy. The energy sensor AMPK has recently been connected to autophagy [37]. Interestingly, the phosphorylation level of AMPK was promoted in $\mathrm{SiHa}$ cells, but it was suppressed in CaSki cells with B5 treatment (Fig. 8A). A complex role of AMPK in B5-mediated autophagy in cervical cancer cell lines is implied. TORC1 is a downstream regulatory target of AKT and AMPK and it usually acts as an autophagysuppressive regulator. TORC1 activity can be followed by the phosphorylation of its substrate 4E-BP1 [35, 38]. As shown in Fig. 8A, the phosphorylation level of 4E-BP1 was decreased in both cell lines upon treatment with B5.

A growing amount of evidences in recent years demonstrate that ROS represent important mediators of autophagy [39]. To investigate the role of ROS in B5-inducd autophagy, CaSki and SiHa cells were pretreated with NAC prior to B5 treatment. As shown in Fig. 8B, LC3-II accumulation was not affected by NAC, suggesting that B5-mediated autophagy induction was independent on B5-caused ROS production in cervical cancer cells. 
A


Figure 6: Effects of B5 on ASK1 and p38/JNK MAPKs. A. CaSki and SiHa cells were treated with $16 \mu$ M B5 for 8h; ASK1Trx complex was precipitated using Protein A beads and analyzed by western blotting with ASK1 and Trx antibodies. B. Activation of p38/JNK MAPKs. Cells were treated with $16 \mu \mathrm{M}$ B5 for 0, 6, 12 and $24 \mathrm{~h}$ and subjected to western blotting analysis; GAPDH was used as the internal control.

\section{Effect of B5-induced autophagy on B5-triggered apoptosis in cervical cancer cells}

To explore whether B5-induced autophagy had a protective or detrimental effect, CaSki and SiHa cells were pre-cultured with two different autophagy inhibitors, 3-MA and $\mathrm{CQ}$, respectively, before the treatment of B5. The MTT assay indicated that 3-MA, a commonly used inhibitor of starvation or rapamycininduced autophagy [40], prevented the inhibitory effect of B5 on the growth of SiHa cell lines (Fig. 9A right), suggesting that B5-induced autophagy may have an apoptosis-promoting effect. To verify this hypothesis, flow cytometry was used to analyze cellular apoptosis induced by the combination of B5 and 3-MA. The results indicate that B5-induced autophagy indeed had an apoptosis-promoting effect but only in $\mathrm{SiHa}$ cells (Fig. 9B bottom).

It has been reported that 3-MA might also inhibit PI3K and can thus promote autophagy in some systems as well as affect cell survival [41]. Another autophagy inhibitor CQ was therefore used to further examine the involvement of autophagy in B5-triggered apoptosis by MTT assay and flow cytometry analysis. As shown in Fig. 9C and 9D, CQ prevented the growth inhibitory effect of B5 and attenuated B5-triggered apoptosis in SiHa cells. However, no obvious changes of growth and apoptosis were observed in CaSki cells when B5 was combined 
A

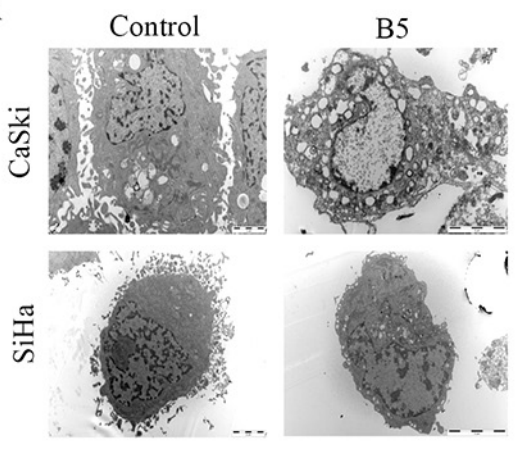

B
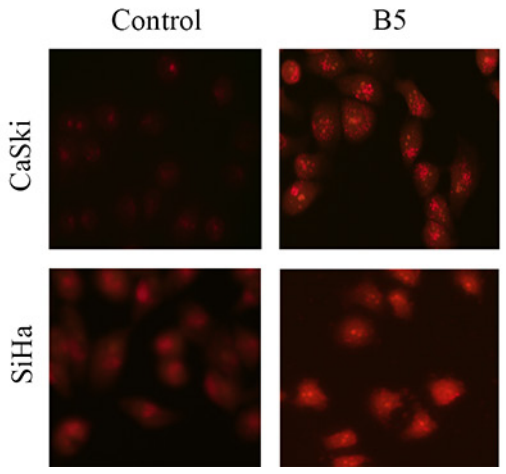

C



$\mathrm{D}$
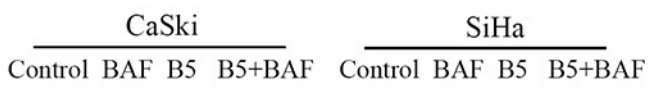

LC3-I

LC3-II

p62

GAPDH

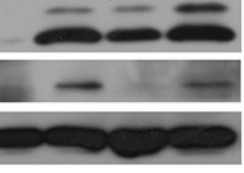

Control CQ B5 B5+CQ

LC3-I

LC3-II

p62

GAPDH

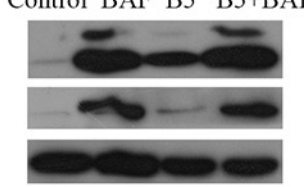

Control CQ B5 B5+CQ

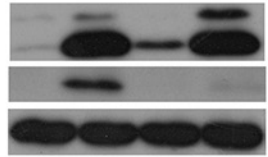

Figure 7: B5-induced autophagy in CaSki and SiHa cells. A. Ultrastructure of CaSki and SiHa cells with the treatment of $16 \mu \mathrm{M}$ B5 for $48 \mathrm{~h}$; transmission electron microscopy shows multiple autophagic vacuoles. B. Cells were treated with B5 for $48 \mathrm{~h}$ and then stained with acridine orange and examined under a fluorescence microscope at magnification of 400. C. Western blotting analysis of LC3 expression in CaSki and SiHa cells with the treatment of $0,4,16$, and $32 \mu \mathrm{M}$ B5 for $48 \mathrm{~h}$. D. Autophagic flux analysis by measuring the expression levels of SQSTM1/p62 or LC3-II. CaSki and SiHa cells were treated with BAF or CQ prior to $16 \mu \mathrm{M}$ B5 treatment for $48 \mathrm{~h}$. Expression levels of SQSTM1/p62 and LC3-II were determined by western blotting analysis.

A

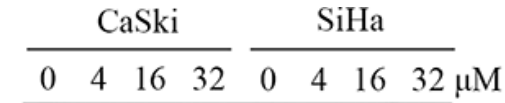

$\mathrm{p}-\mathrm{AKT}$

$\mathrm{AKT}$

-

p-4E-BP

GAPDH

$\mathrm{B}$



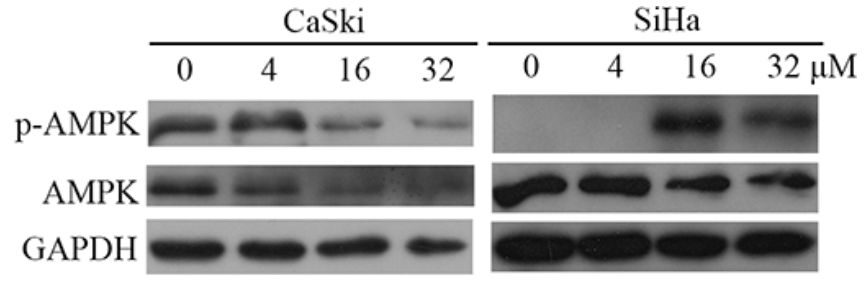

$\mathrm{SiHa}$

Figure 8: A. Expression levels of p-AKT, AKT, p-4E-BP1, AMPK and p-AMPK in CaSki and SiHa cells. Cells were treated with $0,4,16$, and $32 \mu \mathrm{M} \mathrm{B} 5$ for $48 \mathrm{~h}$ and subjected to western blotting analysis. GAPDH was used as the internal control. B. Effect of ROS on B5-inducd autophagy. CaSki and SiHa cells were treated with ROS inhibitor NAC prior to $16 \mu \mathrm{M}$ B5 treatment for 48 h. Expression levels of LC3-II were determined by western blotting analysis. All data are representatives of three independent experiments. 
A
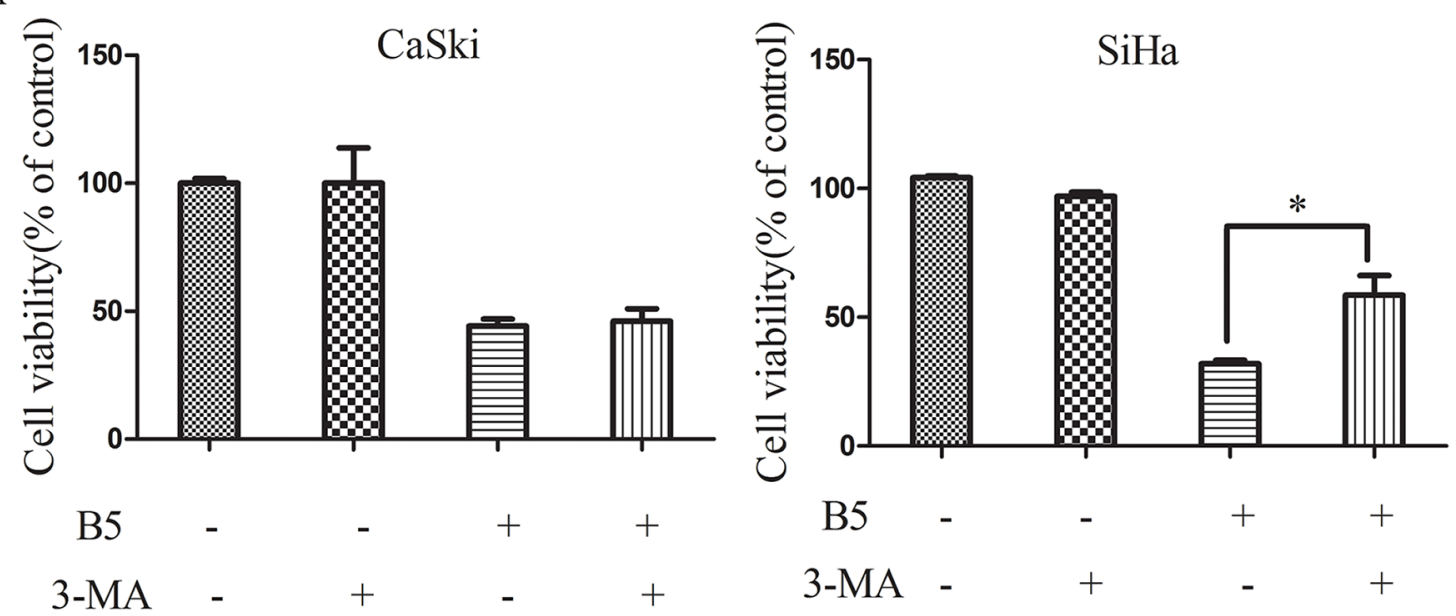

$\mathrm{B}$
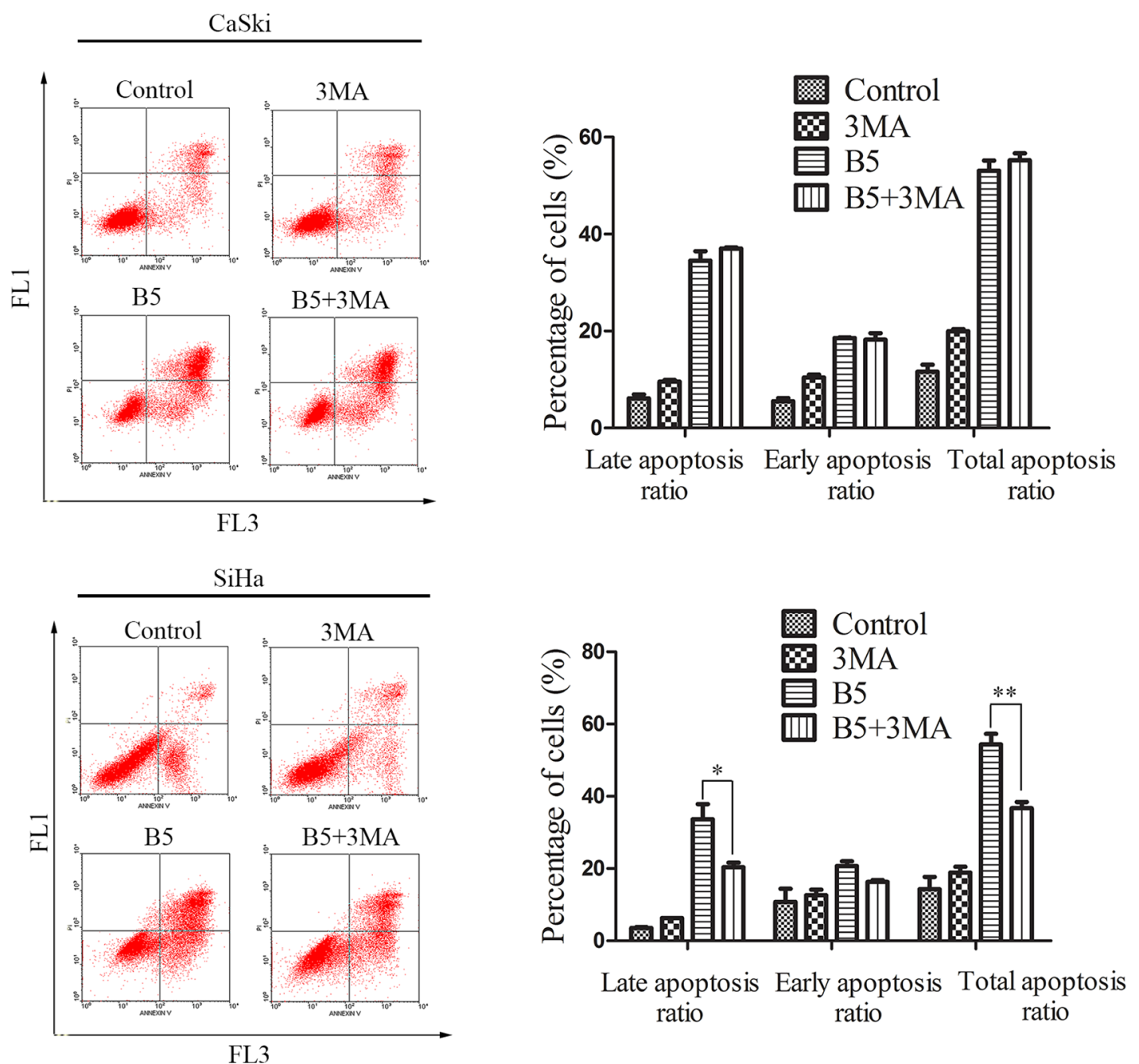

Figure 9: Effects of the autophagy inhibitors, 3-MA and CQ, on B5-induced cell growth inhibition and apoptosis. The cells were pretreated with $5 \mathrm{mM} 3-\mathrm{MA} \mathrm{A}$. and $\mathbf{B}$.

(Continued) 
$\mathrm{C}$
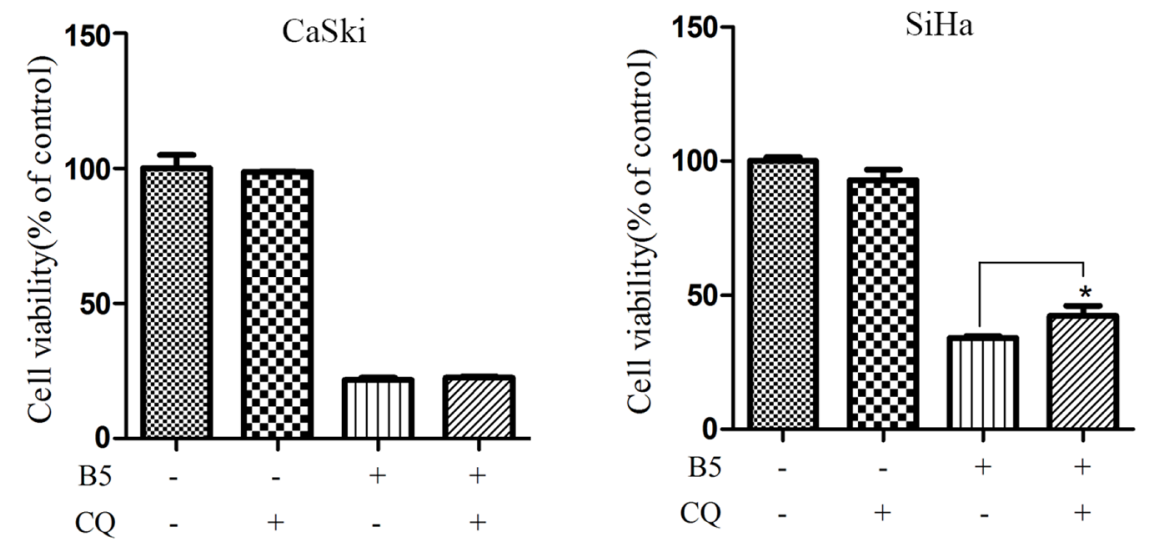

$\mathrm{D}$



FL3
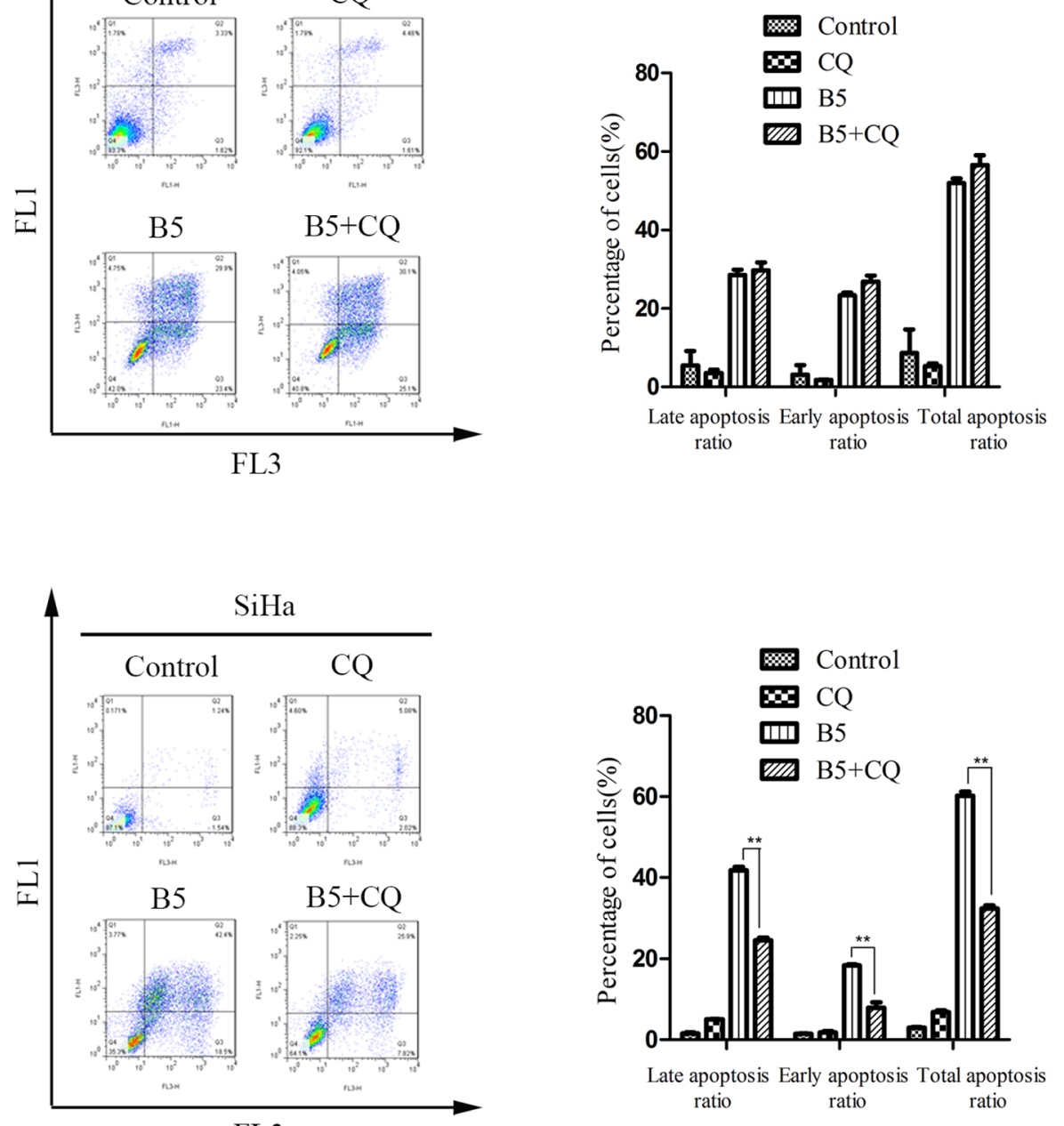

Figure 9: (continued) C. and D. For $1 \mathrm{~h}$ and then treated with $16 \mu \mathrm{M} \mathrm{B} 5$ for $48 \mathrm{~h}$. Cell viability was determined by the MTT assay (A and C). Apoptotic cells were quantified by Annexin V-FITC/PI staining analysis (B and D). Data are presented as the mean \pm SD of three independent experiments. $* P<0.5$ and $* * P<0.01$. 
with CQ. These results suggest that B5-induced autophagy has different roles in B5-induced apoptosis in CaSki and SiHa cells.

\section{DISCUSSION}

The mammalian TrxR is a Sec-containing oxidoreductase that has been established as an anticancer drug target $[4,42,43]$ because of its role as a key player in cell death program [44]. The highly reactive Sec active site with low pKa value and easily accessible location makes this enzyme a suitable target for drug development. In the past decades, many therapeutically used synthetic and natural compounds with TrxR inhibitory activity have been found to exhibit anticancer potential [45]. Among them, gold compounds [46], platinum drugs [47], flavonoids [48], quinines [49], mercury [50], arsenic trioxide [51], curcumin [52] and its analogs [22] have been tested as novel cancer treatments or adjuncts to existing therapy; some of them have shown potent therapeutic effects [53]. In the present study, we demonstrated that B5, a newly synthesized TrxR inhibitor and a curcumin analog, exhibited significant antitumor activity based on the modulation of the intracellular redox status and autophagy (Fig. 10).

Mitochondria plays a very important role as the intrinsic apoptosis pathway [54]. The key event of mitochondrion-induced apoptosis is the permeabilization of the OMM, which occurs in response to various stimuli and is mainly regulated by the members of the Bcl-2 family [28, 29]. Indeed, we found that B5 decreased $\Delta \psi_{\mathrm{m}}$ in CaSki and SiHa cells (Fig. 3B) and downregulated the expression of antiapoptotic $\mathrm{Bcl}-\mathrm{xL}$ while upregulating that of proapoptotic Bid/Bok (Fig. 3A), indicating that the loss of $\Delta \psi_{\mathrm{m}}$ plays an important role in B5-induced apoptosis in cervical cancer cells.

MMP loss is an early event preceding caspase activation, which causes the leakage of small molecules, such as cytochrome $c$ and second mitochondria-derived activator of caspases (Smac), from the mitochondria into the cytoplasm [55], followed by the (a) recruitment of apoptotic protease activating factor-1 (Apaf-1) and procaspase 9 to form the apoptosome [56], (b) activation of caspase 9 and caspase 3 , and (c) execution of apoptosis [57]. The inhibitor of apoptosis (IAP) family negatively regulates this process, and the most potent human IAP protein XIAP inhibits the activity of both caspase 9 and caspase 3 [58]. Our data demonstrate that B5 induced the activation of caspases 3, 8 , and 9 in CaSki and $\mathrm{SiHa}$ cells (Fig. 2C) and downregulated the expression of XIAP (Fig. 2C), indicating that B5 induced apoptosis in cancer cells through the intrinsic as well as extrinsic apoptotic pathways as evidenced by the activation of caspase 8 [43].

The inhibition of TrxR activity results in the accumulation of ROS. In healthy cells, ROS are natural byproducts of metabolism and have important roles in cell signaling and homeostasis. However, excessive ROS generation can damage cell structures and cause oxidative stress and cell death [31]. In our experiments, B5 induced time-dependent ROS accumulation (Fig. 4A) suppression in TrxR activity and increase in the oxidized Trx form (Fig. 5A and 5D) in cancer cells; furthermore, the ROS scavenger NAC reduced B5-elicited apoptosis (Fig. 4B), suggesting that B5-dependent disruption of the Trx system and excessive ROS accumulation underlie the proapoptotic activity of B5. It should be noted that a decrease of ROS level was observed in CaSki and SiHa cells after the treatment of B5 for 4 and $3 \mathrm{~h}$, respectively. It may be that some cellular antioxidant proteins, such as peroxiredoxins, glutathione peroxidase, and catalase, participated in preventing the buildup of intracellular ROS [59].

MAPK signaling pathways are closely involved in the response to oxidative stress [60]. JNK and p38 MAPKs play important roles in regulating $\mathrm{H}_{2} \mathrm{O}_{2}$-induced cell death and are critical mediators of oxidative stressinduced apoptosis $[61,62]$. The binding of reduced Trx to the upstream kinase ASK1 can block JNK and p38 activity; however, when Trx is oxidized, the complex dissociates and the released ASK1 activates the JNK and p38 pathways, thereby promoting apoptosis. Our results show that B5 treatment causes ASK1 dissociation from the complex with Trx in SiHa cells (Fig. 6A) and activation of JNK and p38 MAPKs (Fig. 6B), suggesting that MAPK pathway may be involved in B5-induced apoptosis. The more detailed role of MAPK pathway in B5-induced apoptosis and the relationship between B5-mediated ROS production and MAPKs signal transduction are worthy of further investigation.

Although autophagy can be upregulated in many tumor cells under stress conditions such as chemotherapy or nutrient deficiency, the exact role of autophagy in cancer cell death is still not clear [63, 64]. After short-term stressful effects, autophagy activation generally facilitates the restoration of cell homeostasis and survival. However, under permanent adverse conditions, autophagy is induced to promote elimination of damaged cells by apoptosis [33]. Here, we investigated the association between apoptosis and autophagy in cervical cancer cells treated with the combination of B5 and the autophagy inhibitors. The reduction in autophagy relieved B5 inhibitory effect on cell growth (Fig. 9A and 9C), which is verified by Annexin V-FITC/PI staining analysis in SiHa cells (Fig. 9B and 9D), suggesting a crosstalk between B5-induced apoptosis and autophagy in SiHa cells. However, the treatment of autophagy inhibitors, both 3-MA and CQ, had no effect on B5-induced apoptosis in CaSki cells (Fig. 9), suggesting different signaling pathways may be involved in B5-mediated autophagy in CaSki and SiHa cell lines.

Indeed, in this study, we found that AKT signaling, one of the main signaling pathways regulating autophagy, 
was inconsistently inhibited in CaSki and SiHa cells (Fig. 8A). Although the phosphorylation level of AKT was inhibited markedly at high concentration $(32 \mu \mathrm{M})$ of B5 in both cell lines, it was hardly reduced by 16 $\mu \mathrm{M}$ B5 in SiHa cells in spite of autophagy induction under the treatment of this concentration, indicating the involvement of some other pathway(s) in the regulation of B5-induced autophagy in SiHa cells. Herein AMPK was found to one of the possible regulators. There is mouting evidence that AMPK activates autophagy through inactivation of TORC1 and direct phosphorylation of the protein kinase ULK1 [37]. Our results in Figure 8A that the phosphorylation level of AMPK was elevated dramatically by B5 in SiHa cells suggests that B5 may induce autophagy in $\mathrm{SiHa}$ cells through coordinated regulation of $\mathrm{AKT}$ and $\mathrm{AMPK}$ followed by the suppression of TORC1, whose activity was monitored by the decreased phosphorylation level of 4E-BP1 (Fig. 8A), a substrate of TORC1. It is interesting to note that some unexpected result was observed in CaSki cells, namely the level of phosphorylated AMPK was decreased, which was inconsistent with that of $\mathrm{SiHa}$ cells. It may be that more complex network of regulation are involved in B5mediated autophagy in CaSki cells since the activation of AMPK crucially depends on phosphorylation by multiple upstream kinases, like LKB1, CaMKK, TAK1, etc [65]. The detailed roles of the regulation network in B5mediatd autophagy and crosstalks and feedbacks between B5-induced apoptosis and autophagy remain to be further explored.

In summary, we demonstrated that B5 activated apoptosis in cervical cancer cells via suppression of Trx system and functional disruption of mitochondria. The accumulation of the oxidized Trx would cause ROS accumulation and affect a number of Trx-dependent pathways, including those of ASK1, JNK and p38 MAPKs, which may contribute to B5-induced apoptosis. B5 also promoted apoptosis by induction of autophagy, which might involve the inhibition of the Akt signaling and was independent of ROS (Fig. 10). Our results show that B5 is a more efficient anticancer agent than curcumin in vitro and warrants further in vivo investigation. Our data provide important information for the explanation of the anticancer activity of curcumin analogs and for the development of new curcumin analogs targeting TrxR with high activity against cancer cells.

\section{MATERIALS AND METHODS}

\section{Cell culture and reagents}

The human cervical cancer cell lines CaSki and $\mathrm{SiHa}$ were purchased from the Cell Bank of the Chinese Academy of Sciences (Shanghai, China) and stored in liquid nitrogen. Cells were cultured in DMEM (Gibco,
USA) containing 10\% fetal bovine serum (FBS, Gibco, USA), $100 \mathrm{U} / \mathrm{mL}$ penicillin, and $100 \mu \mathrm{g} / \mathrm{ml}$ streptomycin (complete medium) at $37^{\circ} \mathrm{C}$ in a humidified $5 \% \mathrm{CO}_{2}$ atmosphere.

Curcumin was isolated from Curcuma longa roots and purified by silica gel chromatography. B5 was synthesized in our laboratory as described in a previous report [66].

Dimethylsulfoxide (DMSO), 3-methyladenine autophagy inhibitor (3-MA), 5, 5', 6, 6'-tetrachloro-1, 1', 3, 3 '-tetraethyl-imidacarbocyanine iodide (JC-1), $N$-acetyl1-cysteine (NAC), 2', 7'-dichlorofluoresceindiacetate (DCFH-DA), selenocystine (SC), acridine orange, chloroquine (CQ), bafilomycin $\mathrm{A}_{1}(\mathrm{BAF})$, and 3-(4, 5-dimetrylthiazol-2-yl)-2, 5-diphenyltetrazolium bromide (MTT) were purchased from Sigma (St. Louis, MO, USA). Propidium iodide (PI), RNase and RIAP buffer kit containing protease inhibitors cocktail (phenylmethanesulfonyl fluorideand and leupeptin) and phosphatase inhibitors cocktail (sodium fluoride and sodium orthovanadate) were purchased from Beyotime (Shanghai, China).

Antibodies against the following were purchased from Cell Signaling Technology (Beverly, MA, USA): ASK1; GAPDH; Bax; caspases 3, 8, and 9; X-linked inhibitor of apoptosis (XIAP); PARP; p38; p-p38 MAPK (Thr180/Tyr182); AKT; p-AKT (Ser473); JNK; p-JNK1/2 (Thr183/Tyr185); p-4E-BP1; LC3; AMPK; p-AMPK and SQSTM1/p62. Trx1, TrxR and horseradish peroxidase-conjugated secondary antibodies were purchased from Santa Cruz Biotechnology (Santa Cruz, CA, USA).

\section{Growth inhibition assay}

Growth inhibition of cancer cells by B5 was measured by the MTT assay. Exponentially grown CaSki and SiHa cells were seeded in 96-well plates at the density of $5 \times 10^{3}$ cells per well in complete medium and allowed to attach for about $12 \mathrm{~h}$. Cells were then treated with a range of $\mathrm{B} 5$ concentrations for $48 \mathrm{~h}$. The medium was removed, and $50 \mu \mathrm{l}$ of the same medium containing $5 \mathrm{mg} / \mathrm{ml} \mathrm{MTT} \mathrm{was} \mathrm{added} \mathrm{to} \mathrm{each} \mathrm{well} \mathrm{for} \mathrm{another} 4 \mathrm{~h}$. After medium removal, $100 \mu \mathrm{l}$ DMSO was added to each well for $10 \mathrm{~min}$. Cell viability was assessed by the absorbance at $570 \mathrm{~nm}$ and measured using a microplate reader (BIO-RAD, USA); $\mathrm{IC}_{50}$ values of $\mathrm{B} 5$ for each cell line were determined by comparison with untreated control cells.

\section{Flow cytometry analysis of cell cycle arrest and apoptosis}

CaSki and SiHa cells $\left(2 \times 10^{5}\right)$ were seeded in $60-\mathrm{mm}$ Petri dishes at 1 day before the experiment. For cell cycle analysis, cells were harvested, washed 


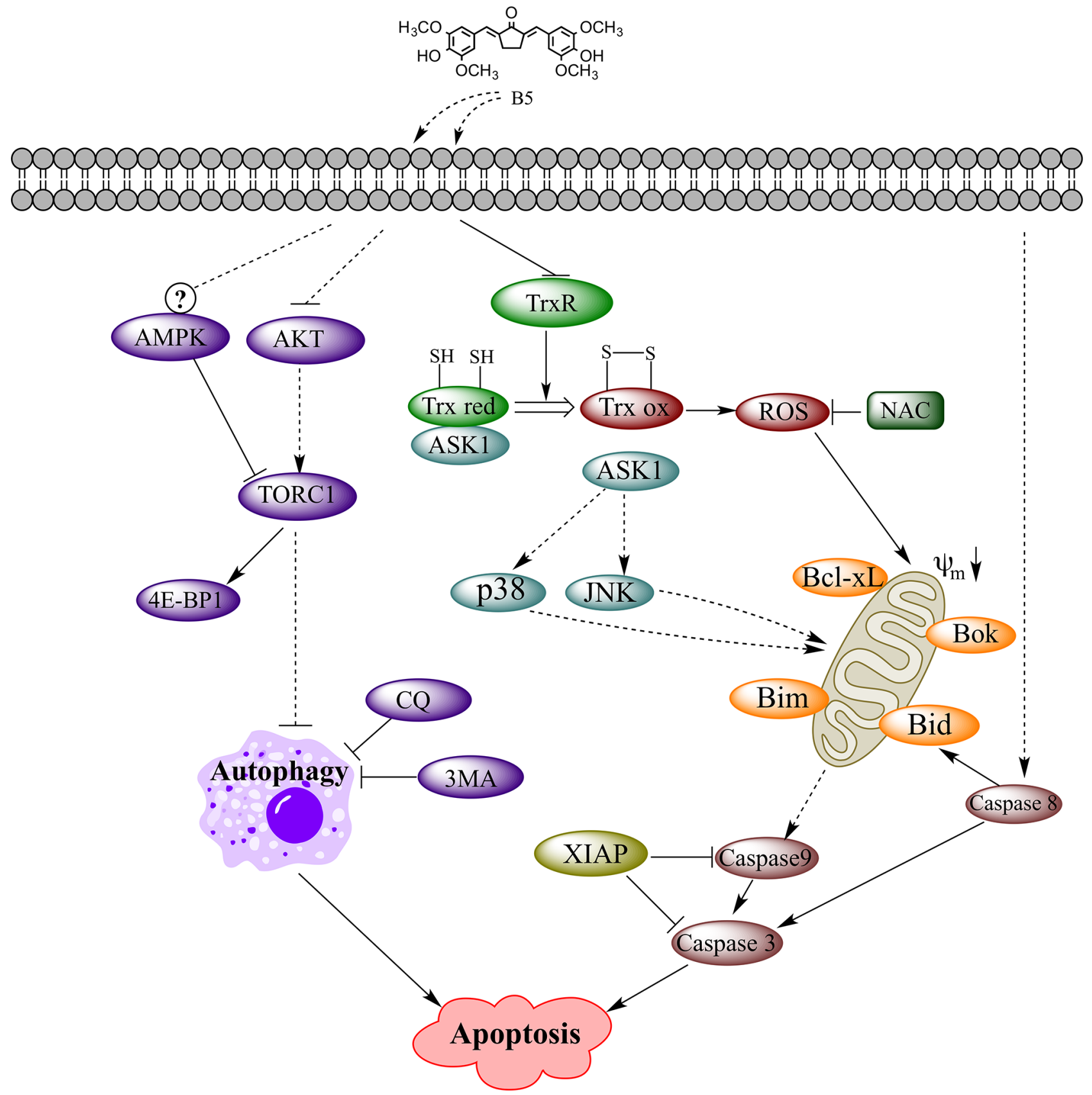

Figure 10: TrxR inhibitor B5-mediated intracellular signaling that led to apoptosis in human cervical cancer cells. Key: black arrows, activation; black blocks, inhibition; dashed arrows or blocks, indirect interaction; circled question mark, complex regulation.

twice with ice-cold PBS, and fixed in $70 \%$ ethanol at $4^{\circ} \mathrm{C}$ overnight after treatment with 4,16 , and $32 \mu \mathrm{M}$ B5 for $48 \mathrm{~h}$. Then cells were washed once with icecold PBS and re-suspended in $1 \mathrm{~mL}$ of staining reagent containing $50 \mathrm{mg} / \mathrm{mL}$ PI and $100 \mathrm{mg} / \mathrm{mL}$ RNase for $30 \mathrm{~min}$ in the dark. To assess apoptosis, harvested cells were washed twice with ice-cold PBS, and stained with Annexin-V-FITC/PI (KeyGEN, Nanjing, China) according to the manufacturer's instructions. Cell cycle arrest and apoptosis were analyzed by flow cytometry (BD FACSCalibur, USA). Fluorescence of
Annexin-V-FITC and PI was monitored at $630 \mathrm{~nm}$ and $525 \mathrm{~nm}$, respectively.

\section{Evaluation of mitochondrial membrane potential (MMP)}

CaSki and SiHa cells $\left(2 \times 10^{5}\right)$ were seeded in 60-mm Petri dishes at 1 day before the experiment. After the treatment with 4,16 , and $32 \mu \mathrm{M} \mathrm{B} 5$ for $48 \mathrm{~h}$, cells were harvested, washed twice with ice-cold PBS, and incubated with JC-1 $(10 \mu \mathrm{g} / \mathrm{ml})$ in the dark for $15 \mathrm{~min}$ at $37^{\circ} \mathrm{C}$. Cells 
were washed three times with ice-cold PBS and analyzed by flow cytometry using emission wavelengths of $590 \mathrm{~nm}$ and $525 \mathrm{~nm}$.

\section{Determination of ROS production}

CaSki and SiHa cells $\left(2 \times 10^{5}\right)$ were seeded in 60-mm Petri dishes. After the treatment with $16 \mu \mathrm{M}$ B5 for $1-4 \mathrm{~h}$, cells were incubated with $10 \mu \mathrm{M}$ DCFH-DA for $15 \mathrm{~min}$ in the dark, washed three times with ice-cold PBS, and seeded in 96-well NUNC plates (Thermo, USA) at the density of $5 \times 10^{3}$ per well; DCFH-DA fluorescence was measured at $525 \mathrm{~nm}$ using a microplate reader (Tecan F500, Switzerland).

\section{Transmission electron microscopy analysis}

CaSki and SiHa cells $\left(2 \times 10^{5}\right)$ were seeded in 60-mm Petri dishes at 1 day before the experiment. After the treatment with $16 \mu \mathrm{M}$ B5 for $48 \mathrm{~h}$, cells were harvested, washed twice with ice-cold PBS, resuspended in $70 \%$ Karnovsky's fixative, and incubated for $20 \mathrm{~min}$ at room temperature. Ultrathin slices were prepared and examined under Hitachi 7000 transmission electron microscope (Tokyo, Japan).

\section{Acridine orange staining}

CaSki and SiHa cells were treated as described in transmission electron microscopy analysis. After harvesting, cells were washed twice with ice-cold PBS and incubated with $1 \mu \mathrm{g} / \mathrm{ml}$ acridine orange for $15 \mathrm{~min}$ at $37^{\circ} \mathrm{C}$. Subsequently, cells were washed three times with ice-cold PBS and then observed under a fluorescence microscope (Olympus IX71, Japan).

\section{Immunoblotting and immunoprecipitation}

After treatment with different concentrations of B5 for $48 \mathrm{~h}$, cells were harvested and washed twice with ice-cold PBS. For immunoblotting analysis, cell lysates were prepared by incubation in RIPA buffer containing protease inhibitors cocktail (1 $\mathrm{mM}$ phenylmethanesulfonyl fluorideand and $1 \mu \mathrm{g} / \mathrm{ml}$ leupeptin) and phosphatase inhibitors cocktail ( $1 \mathrm{mM}$ sodium fluoride and $1 \mathrm{mM}$ sodium orthovanadate) for $30 \mathrm{~min}$ on ice and centrifuged at $12,000 \mathrm{rpm}$ for $15 \mathrm{~min}$. Supernatants were collected, and equal amounts of denatured proteins (heat samples to $95^{\circ} \mathrm{C}$ for $5 \mathrm{~min}$ ) were resolved in SDS-PAGE gels. Proteins were transferred to nitrocellulose membranes, blocked with $5 \%$ nonfat milk at room temperature for $1 \mathrm{~h}$, and incubated with primary antibodies overnight at $4^{\circ} \mathrm{C}$. The membranes were washed three times with Tris-buffered saline-5\% Tween 20 (TBST) solution and incubated with a horseradish peroxidase-conjugated secondary antibody at room temperature for $1 \mathrm{~h}$; protein bands were visualized by enhanced chemiluminescence (Millipore, MA, USA) and analyzed by densitometry.
For immunoprecipitation, equal amounts (according to protein content) of cell lysates prepared as above were incubated with Trx1 antibody immobilized on protein A magnetic beads (Santa Cruz, CA, USA) at $4^{\circ} \mathrm{C}$ overnight. The pellet was washed five times with ice-cold NP40 (Beyotime, Shanghai, China); proteins were extracted with SDS-loading buffer and analyzed by immunoblotting with Trx1 and ASK1 antibodies.

\section{TrxR activity analysis in cells}

TrxR activity in cervical cancer cells was determined by SC-TrxR assay as described by Cunniff et al [67]. Cells were incubated with different concentrations of B5 for $48 \mathrm{~h}$. Cells were harvested and cell lysates were prepared as described above in the presence of protease inhibitors. Protein concentrations of the supernatants were determined by Bradford reagent. $25 \mu \mathrm{g}$ of extract was incubated with $1 \mathrm{mM}$ NADPH and $2 \mathrm{mM} \mathrm{SC}$ in TE buffer (50 mM Tris-HCl and 2 mM EDTA, pH 7.5) in a total volume of $100 \mu \mathrm{l}$. Samples of protein only, protein and NADPH, and protein and SC were used as controls, respectively. The reaction mixture was placed into 96-well microplates and monitored in 30-s intervals over a 20 -min time period at $340 \mathrm{~nm}$ using a microplate reader (BioRad, USA). TrxR activity was expressed as mol NADPH consumed $/ \mathrm{min}$.

\section{Thioredoxin redox status assay}

After the treatment with 4,16 , and $32 \mu \mathrm{M}$ B5 for $48 \mathrm{~h}, 1 \times 10^{6} \mathrm{CaSki}$ and SiHa cells were lysed in $50 \mathrm{mM}$ Tris/ $\mathrm{HCl}, \mathrm{pH}$ 8.3, 3 mM EDTA, $6 \mathrm{M}$ guanidinium chloride, $0.5 \%$ Triton $\mathrm{X}-100$ containing $50 \mathrm{mM}$ iodoacetic acid [68]. After incubation at $37^{\circ} \mathrm{C}$ in the dark for 30 minutes, excess iodoacetic acid was removed using desalting column (Micro Bio-Spin, BIO RAD, USA). Oxidized and reduced Trx-1 were separated by non-reduced SDS-PAGE and immunoblotting.

\section{Quantitative real-time RT-PCR}

CaSki and $\mathrm{SiHa}$ cells $\left(2 \times 10^{5}\right.$ cells/well $)$ were seeded into 6-well plates. After the treatment with 4, 16, and $32 \mu \mathrm{M} \mathrm{B5}$ for $48 \mathrm{~h}$, cells were harvested, and total RNA was isolated using PureLink ${ }^{\mathrm{TM}}$ Viral RNA/DNA Kits (Invitrogen). The quantitative PCR of Trx-1 and TrxR1 mRNA was determined using SYBR Green Realtime PCR Master Mix (Toyobo) as described by the manufacturer. Gene-specific primer pairs used in this study were as follows: TrxR sense 5'-TGTTGAATGAACAACTGTGC-3' and TrxR antisense 5'-TCCTCAGCCAGTACATTGAC-3', Trx sense 5'-CATA ACCAGCCATTGGCTATT-3' and Trx antisense 5'-GCAT AATGTTTATTGTCACG-3', GAPAH sense 5'-CACCCA GAAGACTGTGGATGG-3' and GAPDH antisense 5'-GTCTACATGGCAACTGTGAGG-3'. 


\section{Statistical analysis}

All data are reported as mean $\pm \mathrm{SD}$ of three independent experiments performed in triplicate. The differences between two treatment groups were analyzed by two-tailed unpaired Student's $t$ test; three or more groups were compared by one-way ANOVA multiple comparisons. $P$-values $<0.05$ were regarded as statistically significant.

\section{ACKNOWLEDGMENTS}

This work was supported by grants from the National Natural Science Foundation of China (81001449, 81202427), the Natural Science Foundation of Guangdong Province of China (S2012010008494), the Postdoctoral Science Foundation of China (2013M542334) and the Science Foundation for The Excellent Youth Scholars in University of Guangdong Province of China (LYM11024).

\section{REFERENCES}

1. Lincoln DT, Ali Emadi EM, Tonissen KF, Clarke FM. The thioredoxin-thioredoxin reductase system: over-expression in human cancer. Anticancer Res. 2003; 23:2425-2433.

2. Trachootham D, Zhou Y, Zhang H, Demizu Y, Chen Z, Pelicano H, Chiao PJ, Achanta G, Arlinghaus RB, Liu J, Huang P. Selective killing of oncogenically transformed cells through a ROS-mediated mechanism by betaphenylethyl isothiocyanate. Cancer cell. 2006; 10:241-252.

3. Powis G, Mustacich D, Coon A. The role of the redox protein thioredoxin in cell growth and cancer. Free radical biology \& medicine. 2000; 29:312-322.

4. Urig S, Becker K. On the potential of thioredoxin reductase inhibitors for cancer therapy. Seminars in cancer biology. 2006; 16:452-465.

5. Grogan TM, Fenoglio-Prieser C, Zeheb R, Bellamy W, Frutiger Y, Vela E, Stemmerman G, Macdonald J, Richter L, Gallegos A, Powis G. Thioredoxin, a putative oncogene product, is overexpressed in gastric carcinoma and associated with increased proliferation and increased cell survival. Hum Pathol. 2000; 31:475-481.

6. Kang SW, Rhee SG, Chang TS, Jeong W, Choi MH. 2-Cys peroxiredoxin function in intracellular signal transduction: therapeutic implications. Trends in molecular medicine. 2005; 11:571-578.

7. Rhee SG, Chae HZ, Kim K. Peroxiredoxins: a historical overview and speculative preview of novel mechanisms and emerging concepts in cell signaling. Free radical biology \& medicine. 2005; 38:1543-1552.

8. Zhang P, Liu B, Kang SW, Seo MS, Rhee SG, Obeid LM. Thioredoxin peroxidase is a novel inhibitor of apoptosis with a mechanism distinct from that of Bcl-2. The Journal of biological chemistry. 1997; 272:30615-30618.
9. Saitoh M, Nishitoh H, Fujii M, Takeda K, Tobiume K, Sawada Y, Kawabata M, Miyazono K, Ichijo H. Mammalian thioredoxin is a direct inhibitor of apoptosis signal-regulating kinase (ASK) 1. EMBO J. 1998; 17:2596-2606.

10. Ichijo $H$, Nishida $E$, Irie $K$, ten Dijke $P$, Saitoh $M$, Moriguchi T, Takagi M, Matsumoto K, Miyazono K, Gotoh Y. Induction of apoptosis by ASK1, a mammalian MAPKKK that activates SAPK/JNK and p38 signaling pathways. Science. 1997; 275:90-94.

11. Karlenius TC, Tonissen KF. Thioredoxin and Cancer: A Role for Thioredoxin in all States of Tumor Oxygenation. Cancers. 2010; 2:209-232.

12. Welsh SJ, Bellamy WT, Briehl MM, Powis G. The redox protein thioredoxin-1 (Trx-1) increases hypoxia-inducible factor 1alpha protein expression: Trx-1 overexpression results in increased vascular endothelial growth factor production and enhanced tumor angiogenesis. Cancer Res. 2002; 62:5089-5095.

13. Kaga S, Zhan L, Matsumoto M, Maulik N. Resveratrol enhances neovascularization in the infarcted rat myocardium through the induction of thioredoxin-1, heme oxygenase-1 and vascular endothelial growth factor. J Mol Cell Cardiol. 2005; 39:813-822.

14. Farina AR, Tacconelli A, Cappabianca L, Masciulli MP, Holmgren A, Beckett GJ, Gulino A, Mackay AR. Thioredoxin alters the matrix metalloproteinase/tissue inhibitors of metalloproteinase balance and stimulates human SK-N-SH neuroblastoma cell invasion. European journal of biochemistry / FEBS. 2001; 268:405-413.

15. Ceccarelli J, Delfino L, Zappia E, Castellani P, Borghi M, Ferrini S, Tosetti F, Rubartelli A. The redox state of the lung cancer microenvironment depends on the levels of thioredoxin expressed by tumor cells and affects tumor progression and response to prooxidants. Int J Cancer. 2008; 123:1770-1778.

16. Miyazaki K, Noda N, Okada S, Hagiwara Y, Miyata M, Sakurabayashi I, Yamaguchi N, Sugimura T, Terada M, Wakasugi H. Elevated serum level of thioredoxin in patients with hepatocellular carcinoma. Biotherapy. 1998; 11:277-288.

17. Kim SJ, Miyoshi Y, Taguchi T, Tamaki Y, Nakamura H, Yodoi J, Kato K, Noguchi S. High thioredoxin expression is associated with resistance to docetaxel in primary breast cancer. Clin Cancer Res. 2005; 11:8425-8430.

18. Iwao-Koizumi K, Matoba R, Ueno N, Kim SJ, Ando A, Miyoshi Y, Maeda E, Noguchi S, Kato K. Prediction of docetaxel response in human breast cancer by gene expression profiling. Journal of clinical oncology: official journal of the American Society of Clinical Oncology. 2005; 23:422-431.

19. Marks PA. Thioredoxin in cancer-role of histone deacetylase inhibitors. Seminars in cancer biology. 2006; 16:436-443. 
20. Yoshioka J, Schreiter ER, Lee RT. Role of thioredoxin in cell growth through interactions with signaling molecules. Antioxidants \& redox signaling. 2006; 8:2143-2151.

21. Holmgren A, Bjornstedt M. Thioredoxin and thioredoxin reductase. Methods in enzymology. 1995; 252:199-208.

22. Liu Z, Du ZY, Huang ZS, Lee KS, Gu LQ. Inhibition of thioredoxin reductase by curcumin analogs. Biosci Biotechnol Biochem. 2008; 72:2214-2218.

23. Ho AT, Li QH, Okada H, Mak TW, Zacksenhaus E. XIAP activity dictates Apaf-1 dependency for caspase 9 activation. Molecular and cellular biology. 2007; 27:5673-5685.

24. Scott FL, Denault JB, Riedl SJ, Shin H, Renatus M, Salvesen GS. XIAP inhibits caspase-3 and -7 using two binding sites: evolutionarily conserved mechanism of IAPs. The EMBO journal. 2005; 24:645-655.

25. Singh T, Sharma SD, Katiyar SK. Grape proanthocyanidins induce apoptosis by loss of mitochondrial membrane potential of human non-small cell lung cancer cells in vitro and in vivo. PloS one. 2011; 6:e27444.

26. Charlot JF, Pretet JL, Haughey C, Mougin C. Mitochondrial translocation of p53 and mitochondrial membrane potential (Delta Psi m) dissipation are early events in staurosporineinduced apoptosis of wild type and mutated p53 epithelial cells. Apoptosis: an international journal on programmed cell death. 2004; 9:333-343.

27. Reers M, Smiley ST, Mottola-Hartshorn C, Chen A, Lin M, Chen LB. Mitochondrial membrane potential monitored by JC-1 dye. Methods in enzymology. 1995; 260:406-417.

28. Kuwana T, Mackey MR, Perkins G, Ellisman MH, Latterich M, Schneiter R, Green DR, Newmeyer DD. Bid, Bax, and lipids cooperate to form supramolecular openings in the outer mitochondrial membrane. Cell. 2002; 111:331-342.

29. Schwarz M, Andrade-Navarro MA, Gross A. Mitochondrial carriers and pores: key regulators of the mitochondrial apoptotic program? Apoptosis: an international journal on programmed cell death. 2007; 12:869-876.

30. Vaahtera L, Brosche M, Wrzaczek M, Kangasjarvi J. Specificity in ROS Signaling and Transcript Signatures. Antioxidants \& redox signaling. 2014.

31. Devasagayam TP, Tilak JC, Boloor KK, Sane KS, Ghaskadbi SS, Lele RD. Free radicals and antioxidants in human health: current status and future prospects. The Journal of the Association of Physicians of India. 2004; 52:794-804.

32. Fleury C, Mignotte B, Vayssiere JL. Mitochondrial reactive oxygen species in cell death signaling. Biochimie. 2002; 84:131-141.

33. Booth LA, Tavallai S, Hamed HA, Cruickshanks N, Dent P. The role of cell signalling in the crosstalk between autophagy and apoptosis. Cellular signalling. 2014; 26:549-555.

34. Paglin S, Hollister T, Delohery T, Hackett N, McMahill M, Sphicas E, Domingo D, Yahalom J. A novel response of cancer cells to radiation involves autophagy and formation of acidic vesicles. Cancer Res. 2001; 61:439-444.

35. Klionsky DJ, Abdalla FC, Abeliovich H, Abraham RT, Acevedo-Arozena A, Adeli K, Agholme L, Agnello M, Agostinis P, Aguirre-Ghiso JA, Ahn HJ, Ait-Mohamed O, Ait-Si-Ali S, Akematsu T, Akira S, Al-Younes HM, et al. Guidelines for the use and interpretation of assays for monitoring autophagy. Autophagy. 2012; 8:445-544.

36. Shinojima N, Yokoyama T, Kondo Y, Kondo S. Roles of the Akt/mTOR/p70S6K and ERK1/2 signaling pathways in curcumin-induced autophagy. Autophagy. 2007; $3: 635-637$.

37. Hardie DG. AMPK and autophagy get connected. The EMBO journal. 2011; 30:634-635.

38. Yip CK, Murata K, Walz T, Sabatini DM, Kang SA. Structure of the human mTOR complex I and its implications for rapamycin inhibition. Molecular cell. 2010; 38:768-774.

39. Navarro-Yepes J, Burns M, Anandhan A, Khalimonchuk O, del Razo LM, Quintanilla-Vega B, Pappa A, Panayiotidis MI, Franco R. Oxidative stress, redox signaling, and autophagy: cell death versus survival. Antioxidants \& redox signaling. 2014; 21:66-85.

40. Seglen PO, Gordon PB. 3-Methyladenine: specific inhibitor of autophagic/lysosomal protein degradation in isolated rat hepatocytes. Proc Natl Acad Sci U S A. 1982; 79:1889-1892.

41. Wu YT, Tan HL, Shui G, Bauvy C, Huang Q, Wenk MR, Ong CN, Codogno P, Shen HM. Dual role of 3-methyladenine in modulation of autophagy via different temporal patterns of inhibition on class I and III phosphoinositide 3-kinase. The Journal of biological chemistry. 2010; 285:10850-10861.

42. Mukherjee A, Martin SG. The thioredoxin system: a key target in tumour and endothelial cells. Br J Radiol. 2008; 81:S57-68.

43. Tonissen KF, Di Trapani G. Thioredoxin system inhibitors as mediators of apoptosis for cancer therapy. Mol Nutr Food Res. 2009; 53:87-103.

44. Lu J, Holmgren A. Thioredoxin system in cell death progression. Antioxidants \& redox signaling. 2012; 17:1738-1747.

45. Arner ES. Focus on mammalian thioredoxin reductasesimportant selenoproteins with versatile functions. Biochim Biophys Acta. 2009; 1790:495-526.

46. Liu JJ, Liu Q, Wei HL, Yi J, Zhao HS, Gao LP. Inhibition of thioredoxin reductase by auranofin induces apoptosis in adriamycin-resistant human K562 chronic myeloid leukemia cells. Die Pharmazie. 2011; 66:440-444.

47. Yokomizo A, Ono M, Nanri H, Makino Y, Ohga T, Wada M, Okamoto T, Yodoi J, Kuwano M, Kohno K. Cellular levels of thioredoxin associated with drug 
sensitivity to cisplatin, mitomycin $\mathrm{C}$, doxorubicin, and etoposide. Cancer Res. 1995; 55:4293-4296.

48. Lu J, Papp LV, Fang J, Rodriguez-Nieto S, Zhivotovsky B, Holmgren A. Inhibition of Mammalian thioredoxin reductase by some flavonoids: implications for myricetin and quercetin anticancer activity. Cancer Res. 2006; 66:4410-4418.

49. Xia L, Nordman T, Olsson JM, Damdimopoulos A, Bjorkhem-Bergman L, Nalvarte I, Eriksson LC, Arner ES, Spyrou G, Bjornstedt M. The mammalian cytosolic selenoenzyme thioredoxin reductase reduces ubiquinone. A novel mechanism for defense against oxidative stress. The Journal of biological chemistry. 2003; 278:2141-2146.

50. Carvalho CM, Chew EH, Hashemy SI, Lu J, Holmgren A. Inhibition of the human thioredoxin system. A molecular mechanism of mercury toxicity. The Journal of biological chemistry. 2008; 283:11913-11923.

51. Lu J, Chew EH, Holmgren A. Targeting thioredoxin reductase is a basis for cancer therapy by arsenic trioxide. Proc Natl Acad Sci U S A. 2007; 104:12288-12293.

52. Fang J, Lu J, Holmgren A. Thioredoxin reductase is irreversibly modified by curcumin: a novel molecular mechanism for its anticancer activity. The Journal of biological chemistry. 2005; 280:25284-25290.

53. Chen GQ, Zhu J, Shi XG, Ni JH, Zhong HJ, Si GY, Jin XL, Tang W, Li XS, Xong SM, Shen ZX, Sun GL, Ma J, Zhang P, Zhang TD, Gazin C, et al. In vitro studies on cellular and molecular mechanisms of arsenic trioxide (As2O3) in the treatment of acute promyelocytic leukemia: As2O3 induces NB4 cell apoptosis with downregulation of Bcl-2 expression and modulation of PML-RAR alpha/PML proteins. Blood. 1996; 88:1052-1061.

54. Green DR, Reed JC. Mitochondria and apoptosis. Science. 1998; 281:1309-1312.

55. Orrenius S, Gogvadze V, Zhivotovsky B. Mitochondrial oxidative stress: implications for cell death. Annual review of pharmacology and toxicology. 2007; 47:143-183.

56. Zou H, Li Y, Liu X, Wang X. An APAF-1.cytochrome c multimeric complex is a functional apoptosome that activates procaspase-9. The Journal of biological chemistry. 1999; 274:11549-11556.

57. Srinivasula SM, Ahmad M, FernandesAlnemri T, Alnemri ES. Autoactivation of procaspase-9 by Apaf-1-mediated oligomerization. Molecular cell. 1998; 1:949-957.

58. Deveraux QL, Roy N, Stennicke HR, Van Arsdale T, Zhou Q, Srinivasula SM, Alnemri ES, Salvesen GS, Reed JC. IAPs block apoptotic events induced by caspase- 8 and cytochrome $\mathrm{c}$ by direct inhibition of distinct caspases. The EMBO journal. 1998; 17:2215-2223.

59. Schieber M, Chandel NS. ROS function in redox signaling and oxidative stress. Curr Biol. 2014; 24:R453-462.

60. Runchel C, Matsuzawa A, Ichijo H. Mitogen-activated protein kinases in mammalian oxidative stress responses. Antioxidants \& redox signaling. 2011; 15:205-218.

61. Owuor ED, Kong AN. Antioxidants and oxidants regulated signal transduction pathways. Biochemical pharmacology. 2002; 64:765-770.

62. Pocrnich CE, Liu H, Feng M, Peng T, Feng Q, Hutnik CM. p38 mitogen-activated protein kinase protects human retinal pigment epithelial cells exposed to oxidative stress. Canadian journal of ophthalmology Journal canadien d'ophtalmologie. 2009; 44:431-436.

63. Liu B, Cheng Y, Zhang B, Bian HJ, Bao JK. Polygonatum cyrtonema lectin induces apoptosis and autophagy in human melanoma A375 cells through a mitochondria-mediated ROS-p38-p53 pathway. Cancer letters. 2009; 275:54-60.

64. Wang Q, Chen Z, Diao X, Huang S. Induction of autophagy-dependent apoptosis by the survivin suppressant YM155 in prostate cancer cells. Cancer letters. 2011; 302:29-36.

65. Alers S, Loffler AS, Wesselborg S, Stork B. Role of AMPK-mTOR-Ulk1/2 in the regulation of autophagy: cross talk, shortcuts, and feedbacks. Molecular and cellular biology. 2012; 32:2-11.

66. Du ZY, Bao YD, Liu Z, Qiao W, Ma L, Huang ZS, Gu LQ, Chan AS. Curcumin analogs as potent aldose reductase inhibitors. Archiv der Pharmazie. 2006; 339:123-128.

67. Cunniff B, Snider GW, Fredette N, Hondal RJ, Heintz NH. A direct and continuous assay for the determination of thioredoxin reductase activity in cell lysates. Analytical biochemistry. 2013.

68. Watson WH, Pohl J, Montfort WR, Stuchlik O, Reed MS, Powis G, Jones DP. Redox potential of human thioredoxin 1 and identification of a second dithiol/disulfide motif. The Journal of biological chemistry. 2003; 278:33408-33415. 